\title{
Performance Enhancement of Dye-Sensitized Solar Cells Using a Natural Sensitizer
}

\author{
Zainal Arifin, ${ }^{1,2}$ Sudjito Soeparman, ${ }^{1}$ Denny Widhiyanuriyawan, ${ }^{1}$ and Suyitno Suyitno ${ }^{2}$ \\ ${ }^{1}$ Department of Mechanical Engineering, Brawijaya University, Jl. Veteran, Malang 65145, Indonesia \\ ${ }^{2}$ Department of Mechanical Engineering, Sebelas Maret University, Jl. Ir. Sutami 36 A, Surakarta 57126, Indonesia \\ Correspondence should be addressed to Zainal Arifin; zainal_arifin@staff.uns.ac.id
}

Received 26 October 2016; Revised 22 December 2016; Accepted 29 December 2016; Published 24 January 2017

Academic Editor: K. R. Justin Thomas

Copyright (c) 2017 Zainal Arifin et al. This is an open access article distributed under the Creative Commons Attribution License, which permits unrestricted use, distribution, and reproduction in any medium, provided the original work is properly cited.

\begin{abstract}
Dye-sensitized solar cells (DSSCs) based on natural sensitizers have become a topic of significant research because of their urgency and importance in the energy conversion field and the following advantages: ease of fabrication, low-cost solar cell, and usage of nontoxic materials. In this study, the chlorophyll extracted from papaya leaves was used as a natural sensitizer. Dye molecules were adsorbed by $\mathrm{TiO}_{2}$ nanoparticle surfaces when submerged in the dye solution for $24 \mathrm{~h}$. The concentration of the dye solution influences both the amount of dye loading and the DSSC performance. The amount of adsorbed dye molecules by $\mathrm{TiO}_{2}$ nanoparticle was calculated using a desorption method. As the concentration of dye solution was increased, the dye loading capacity and power conversion efficiency increased. Above $90 \mathrm{mM}$ dye solution concentration, however, the DSSC efficiency decreased because dye precipitated on the $\mathrm{TiO}_{2}$ nanostructure. These characteristics of DSSCs were analyzed under the irradiation of $100 \mathrm{~mW} / \mathrm{cm}^{2}$. The best performance of DSSCs was obtained at $90 \mathrm{mM}$ dye solution, with the values of $V_{\mathrm{oc}}, J_{\mathrm{sc}}$, FF, and efficiency of DSSCs being $0.561 \mathrm{~V}, 0.402 \mathrm{~mA} / \mathrm{cm}^{2}, 41.65 \%$, and $0.094 \%$, respectively.
\end{abstract}

\section{Introduction}

Performance of dye-sensitized solar cells (DSSCs) is influenced by semiconductors, electrolytes, transparent conductive oxide (TCO) substrates, counter electrode, and dye sensitizers [1-6]. Dye plays an important role in the performance of DSSCs [7-9]. When synthetic dye such as ruthenium complex is used as a sensitizer in a wide-bandgap semiconductor, the DSSC efficiency becomes over 10\% [3]. Because of high costs, presence of heavy metals, and complex synthesis processes of synthetic dyes, natural dyes obtained from leaves, fruits, and plants are a cheaper option and they are nontoxic and completely biodegradable also [10].

Performance of DSSCs based natural sensitizer can be enhanced by using chlorophyll. When ethanol is used as a solvent, the efficiency of DSSCs improves to $36.11 \%$ compared to that achieved when distilled water is used [10]. The acidity of chlorophyll solution can be controlled to $\mathrm{pH} 3.5$ by adding benzoic acid, which helped increase the efficiency of DSSCs from $0.07 \%$ to $0.28 \%$ [11]. The amount of dye molecules that can be absorbed by the semiconductor is also essential in improving the performance and the electron injection of DSSCs [12]. High electron injection from photoexcited sensitizers to the conduction band of semiconductors strongly influences the current density of DSSCs [1].

The amount of dye adsorbed by semiconductors can be studied by controlling the size of the semiconductor and modifying the morphological structure of the semiconductor [12-16]. The properties of the dye solution can also affect the amount of dye molecules adsorbed by semiconductors [17]. One of the solution's properties that can be easily controlled is the concentration of the solution. The dye solution concentration on the semiconductor is also important for study because of its influence in DSSC performance. In this work, the performance of DSSCs with natural chlorophyll as the sensitizer at various concentrations was studied. The performance of chlorophyll-based DSSCs was compared with the results obtained using N719-based DSSCs. 


\section{Material and Method}

2.1. Chlorophyll Dye Synthesis. The chlorophyll dye extracted from $100 \mathrm{~g}$ of papaya leaves was added to $1 \mathrm{~L}$ of ethyl alcohol (96\%, Merck, Germany) and heated at $70^{\circ} \mathrm{C}$ for $3 \mathrm{~h}$. The separation of this solution was performed using Buchner funnel with single number 42 Whatman filter paper. The extracted dyes were then isolated from the ethanolic solution by rotary evaporation and got $8.5 \mathrm{~g}$ of crude chlorophyll. The crude chlorophyll was added to petroleum ether until a yellow color appears in the column chromatography. The separation process was followed by replacing the eluent with a solution of $10 \%$ diethyl ether in petroleum ether to produce $0.76 \mathrm{~g}(8.9 \%)$ chlorophyll (green), $0.035 \mathrm{~g}(0.41 \%) \beta$-carotene (yellow), $0.03(0.35 \%)$ phycoerythrin (orange), and residues. A detailed description of the synthesis of chlorophyll dyes can be found elsewhere [11]. The chlorophyll was dissolved in ethyl alcohol to obtain solution of various concentrations $(60,70,80,90$, and $100 \mathrm{mM})$. The synthetic dye used in this research was $0.03 \mathrm{mM}$ N719 (Dyesol). The optical properties of the dyes were measured by UV-Vis spectroscopy (Lambda 25, Perkin Elmer). The functional groups in the dyes were characterized by Fourier transform infrared spectroscopy (FTIR, Shimadzu). Cyclic voltammetry (CV, Metrohm AG) was used to determine the reduction and oxidation potentials ( $E_{\text {red }}$ and $E_{\text {ox }}$, resp.) of the dyes. The Pt wire, Pt plate, and $\mathrm{Ag} / \mathrm{AgCl}$ were used as a counter, working, and reference electrodes, respectively. The potential applied in the CV process was from $-2.0 \mathrm{~V}$ to $+2.0 \mathrm{~V}$ with a scan rate of $100 \mathrm{mV} / \mathrm{s}$

2.2. DSSC Fabrication and Testing. The DSSCs were assembled as follows: fluorine-doped tin oxide (FTO, SigmaAldrich) conductive glasses were used as the substrate. The semiconductor paste was prepared by dissolving $0.24 \mathrm{~g} \mathrm{TiO}_{2}$ nanopowder ( $21 \mathrm{~nm}$, Sigma-Aldrich) into $4 \mathrm{~mL}$ ethyl alcohol (96\%, Merck). The $\mathrm{TiO}_{2}$ paste was applied to FTO-coated glass and flattened using the doctor blade method until the $\mathrm{TiO}_{2}$ film becomes a homogenous layer. The semiconductor layer was maintained at $20 \mu \mathrm{m}$ and an area of $1 \times 1 \mathrm{~cm}^{2}$. Then, the $\mathrm{TiO}_{2}$ layer coated on the FTO substrate was sintered at $450^{\circ} \mathrm{C}$ for $2.5 \mathrm{~h}$ to enhance the bonding between the semiconductor and the FTO glass. After that, the photoelectrodes were immersed in the respective dye solution for $24 \mathrm{~h}$ at $30^{\circ} \mathrm{C}$.

The counter electrode was conducted by a sputtering process. The catalytic platinum was deposited on the FTO glass in a vacuum tube at $9.5 \times 10^{-5}$ Torr. The platinum material target was connected to the negative terminal at a high voltage of $404 \mathrm{~V}$ and $125 \mathrm{~mA}$, while the FTO glass was connected to the positive terminal. The electrolyte solution was synthesized by mixing $3.3 \mathrm{~g}$ sodium iodide (99.95\%), $523.875 \mathrm{mg}$ pure iodine (99.95\%), $5.481 \mathrm{~g}$ heteropolyacid (HPA), and $30 \mathrm{~mL}$ acetonitrile. HPA added in the electrolyte act as an electron acceptor to prevent recombination and photoreduction of iodide $\left(\mathrm{I}^{-}\right)$[18]. The electrolyte solution was injected into the assembled DSSCs at $30 \mu \mathrm{m}$ intervals and sealed by glass glue. The performance of DSSCs was determined by a solar

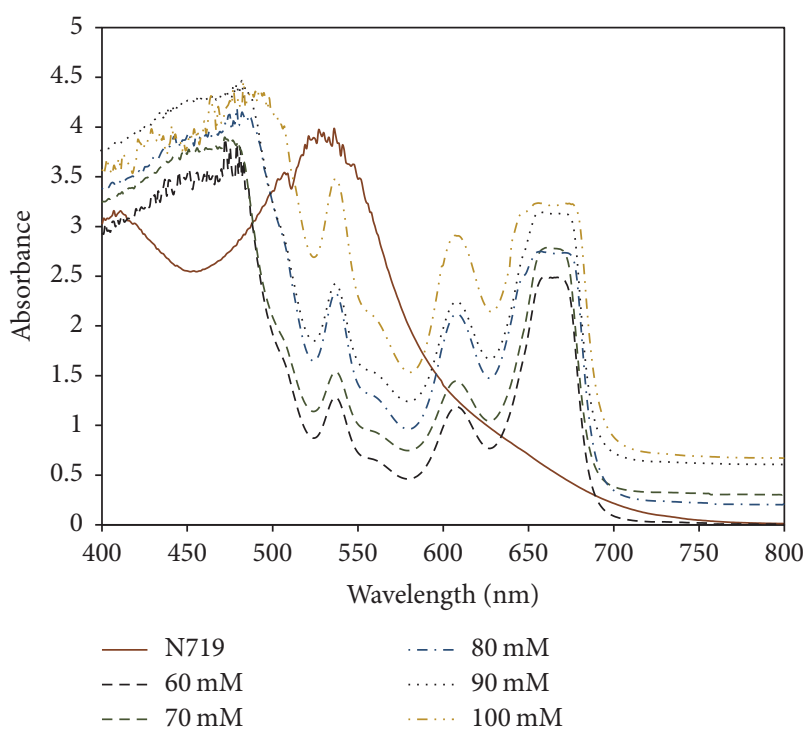

FIgURE 1: Absorption spectra of N719 and chlorophyll dyes.

simulator under irradiation of $100 \mathrm{~mW} / \mathrm{cm}^{2}$. The currentvoltage $(I-V)$ curve was measured by a digital multimeter (Keithley 2401) to obtain $J_{\mathrm{sc}}, V_{\mathrm{oc}}$, FF, and efficiency of DSSCs.

\section{Results and Discussion}

3.1. Dye Characterization. The absorption spectra in the visible light spectrum (400-700 nm) of N719 and chlorophyll dyes are shown in Figure 1. The absorption peak of N719 can be seen at $515 \mathrm{~nm}$ and chlorophyll at $660 \mathrm{~nm}$ [11]. Variation in the chlorophyll dye solution concentration did not affect the position of the absorption peak spectra but affected the absorbance value at a wavelength of $660 \mathrm{~nm}$. This corresponds with the Lambert-Beer law, according to which the absorbance of a solution is proportional to its concentration at the same path length of the light beam [19].

Figure 2 and Table 1 show the cyclic voltammetry (CV) test results of N719 and chlorophyll dyes. The electrochemical oxidation and reduction onset potentials ( $E_{\text {ox }}$ and $E_{\text {red }}$, resp.) were used to calculate the energy levels of the highest occupied molecular orbital $\left(E_{\mathrm{HOMO}}\right)$ and the lowest unoccupied molecular orbital ( $\left.E_{\text {LUMO }}\right)$ [11]. The onset potentials were determined from the intersection of tangents between the rising current and the baseline charging current of the $\mathrm{CV}$ curves. As shown in Table 1, the various concentrations have a minor effect on $E_{\mathrm{HOMO}}$ and $E_{\mathrm{LUMO}}$ values of chlorophyll dyes. Figure 3 shows the FTIR measurements of N719 and chlorophyll dyes. All dyes display peaks in both the 25003000 and $1600-1750 \mathrm{~cm}^{-1}$ region, corresponding to the presence of the $-\mathrm{OH}$ and $\mathrm{C}=\mathrm{O}$ groups, respectively. However, the N719 dye produced more $\mathrm{C}=\mathrm{O}$ stretching and $-\mathrm{OH}$ groups than chlorophyll dyes. In general, the concentration variation in chlorophyll dyes did not change the $\mathrm{C}=\mathrm{O}$ stretching and $-\mathrm{OH}$ groups. 
TABLE 1: Energy levels of N719 and chlorophyll dyes.

\begin{tabular}{|c|c|c|c|c|c|}
\hline Dyes & $E_{\text {ox }}(\mathrm{V})$ & $E_{\text {HOMO }}{ }^{a}(\mathrm{eV})$ & $E_{\text {red }}(\mathrm{V})$ & $E_{\text {LUMO }}{ }^{\mathrm{b}}(\mathrm{eV})$ & $E_{\text {Band Gap }}(\mathrm{eV})$ \\
\hline N719 & 0.68 & -5.08 & -1.22 & -3.18 & 1.90 \\
\hline $60 \mathrm{mM}$ chlorophyll & 0.71 & -5.11 & -0.76 & -3.64 & 1.47 \\
\hline $70 \mathrm{mM}$ chlorophyll & 0.77 & -5.17 & -0.76 & -3.64 & 1.53 \\
\hline $80 \mathrm{mM}$ chlorophyll & 0.77 & -5.17 & -0.78 & -3.62 & 1.55 \\
\hline $90 \mathrm{mM}$ chlorophyll & 0.75 & -5.15 & -0.76 & -3.64 & 1.51 \\
\hline $100 \mathrm{mM}$ chlorophyll & 0.72 & -5.12 & -0.70 & -3.70 & 1.42 \\
\hline
\end{tabular}

${ }^{\mathrm{a}} E_{\mathrm{HOMO}}=-e\left[E_{\mathrm{OX}}+4.4\right]$.

${ }^{\mathrm{b}} E_{\mathrm{LUMO}}=-e\left[E_{\mathrm{red}}+4.4\right]$.

TABLE 2: Characteristics of DSSCs based on N719 and chlorophyll dyes.

\begin{tabular}{lccccc}
\hline Dyes & $V_{\mathrm{OC}}(\mathrm{V})$ & $J_{\mathrm{SC}}\left(\mathrm{mA} / \mathrm{cm}^{2}\right)$ & $\mathrm{FF}(\%)$ & $\eta(\%)$ & Dye loading $\left(\mathrm{mol} / \mathrm{cm}^{2}\right)$ \\
\hline N719 & 0.553 & 5.612 & 41.63 & 1.293 & $1.0 \times 10^{-7}$ \\
$60 \mathrm{mM}$ chlorophyll & 0.542 & 0.169 & 44.02 & 0.040 & $5.7 \times 10^{-8}$ \\
70 mM chlorophyll & 0.501 & 0.188 & 48.16 & 0.045 & $8.4 \times 10^{-8}$ \\
80 mM chlorophyll & 0.594 & 0.401 & 39.55 & 0.074 & $9.8 \times 10^{-8}$ \\
90 mM chlorophyll & 0.561 & 0.402 & 41.65 & 0.094 & $1.1 \times 10^{-7}$ \\
100 mM chlorophyll & 0.606 & 0.346 & 42.34 & 0.049 & $1.3 \times 10^{-7}$ \\
\hline
\end{tabular}

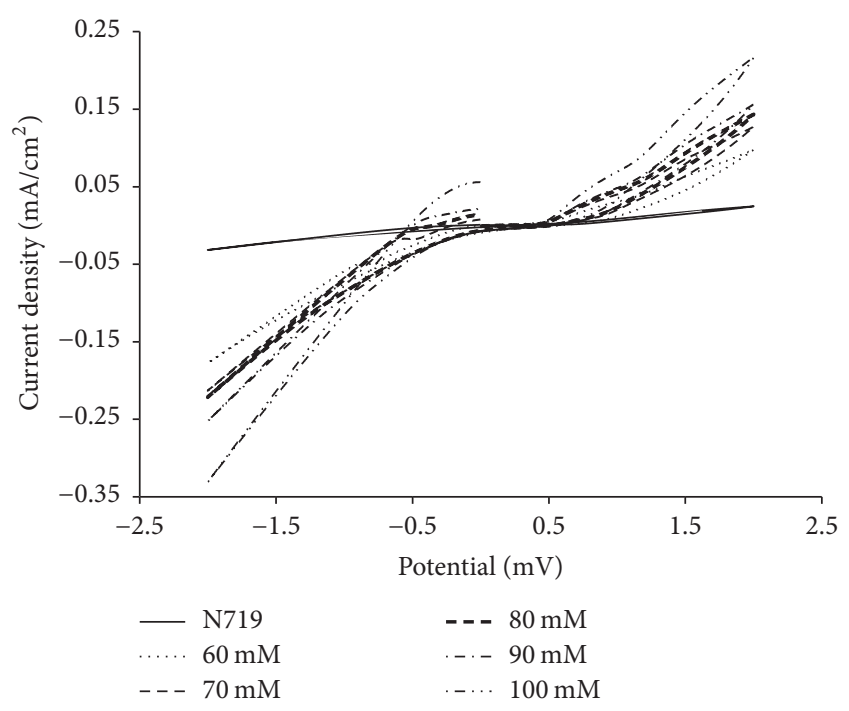

Figure 2: Cyclic voltammogram curves of N719 and chlorophyll dyes.

3.2. Performance of DSSCs. Figure 4 and Table 2 show the performance of DSSCs based on N719 and chlorophyll dyes under irradiation of $100 \mathrm{~mW} / \mathrm{cm}^{2}$. The energy conversion efficiency of N719 dye-based DSSCs was higher than all chlorophyll dye-based DSSCs. The N719 dye-based DSSCs achieved an efficiency of $1.293 \%$, while the highest efficiency of chlorophyll dye-based DSSCs was $0.094 \%$ at $90 \mathrm{mM}$.

The amount of dye loading on the semiconductor surface was measured by the dye desorption method [12]. This process was followed by the immersion of the $\mathrm{TiO}_{2}$-dye electrode in an ethanol solution of $0.1 \mathrm{M} \mathrm{NaOH}$. The dye desorption took place after $1 \mathrm{~h}$, with the solution becoming pink for the N719 dye and green for the chlorophyll dye. At

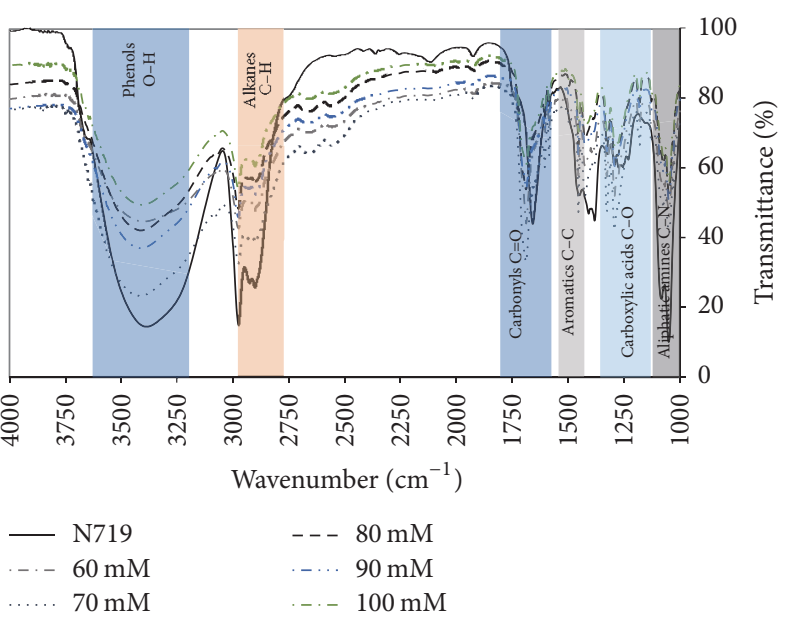

FIGURE 3: FTIR spectra of N719 and chlorophyll dyes.

the same time, the $\mathrm{TiO}_{2}$ electrode turned colorless because it loses the dye on its surface [12, 20]. Figure 5 shows the UV-Vis absorption spectra of the solutions measured to estimate the concentration of the adsorbed dye molecules. The concentration of the adsorbed dye was calculated by using the Lambert-Beer law:

$$
A=\varepsilon \cdot c \cdot l,
$$

where $A$ is the intensity of the UV-Vis absorption spectra at the peak of N719 and chlorophyll dye in 515 and $660 \mathrm{~nm}$, respectively, $\varepsilon$ is the molar extinction coefficient of dye, $c$ is the dye molecular concentration, and $l$ is the path length of the light beam. The molar extinction coefficient of N719 determined to be $14,100 \mathrm{M}^{-1} \mathrm{~cm}^{-1}$ at $515 \mathrm{~nm}[12,21]$ and for chlorophyll is $86,300 \mathrm{M}^{-1} \mathrm{~cm}^{-1}$ at $660 \mathrm{~nm}$ [22]. 


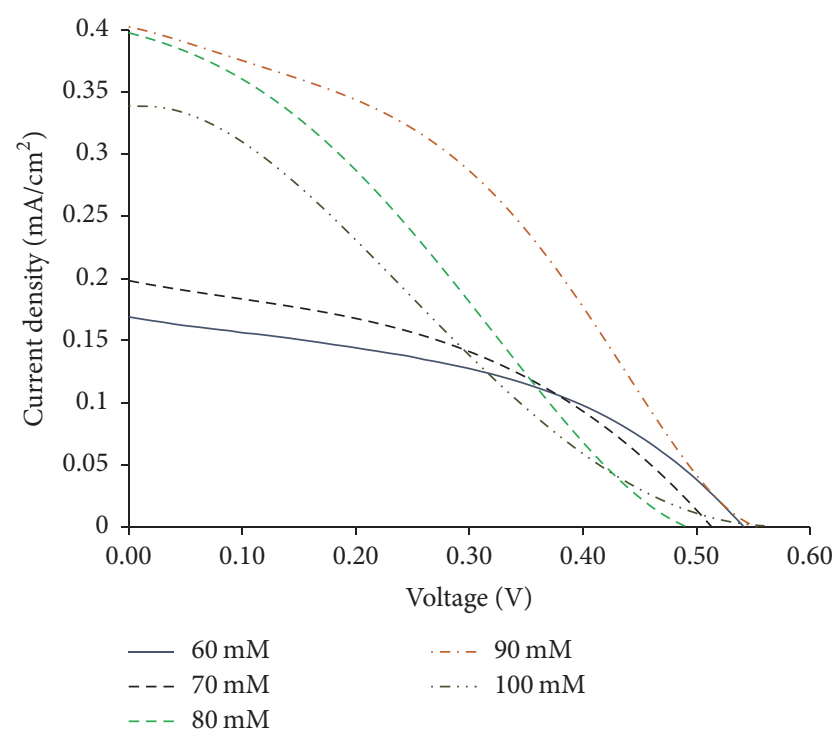

FIGURE 4: $I-V$ curves of DSSCs under irradiation intensity of $100 \mathrm{~mW} / \mathrm{cm}^{2}$.

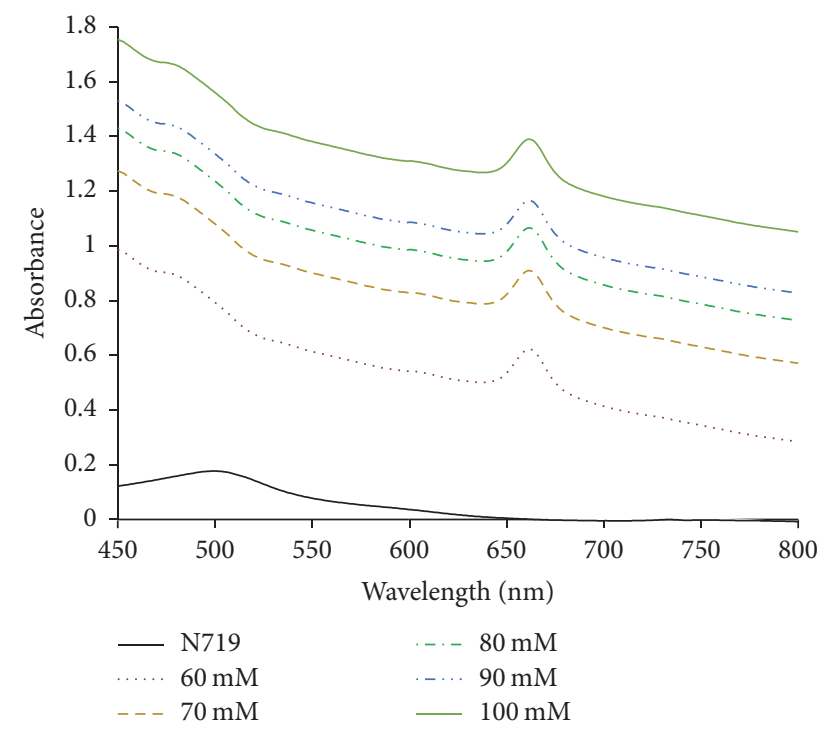

FIGURE 5: UV-Vis absorption spectra of the solutions containing dyes detached from $\mathrm{TiO}_{2}$ electrode.

Increasing the concentration of chlorophyll dyes increased the DSSC efficiency and was seen by the increase in the current density $\left(J_{\mathrm{SC}}\right)$. The rise in current density is associated with the amount of dye that can be adsorbed by the $\mathrm{TiO}_{2}$ electrodes [1]. However, at concentrations above $90 \mathrm{mM}$, the dye loading value increased, while the efficiency of DSSCs decreased. This result can be explained by the precipitation of dyes on the $\mathrm{TiO}_{2}$ electrodes. Because of this phenomenon, some dissolution of $\mathrm{TiO}_{2}$ by the acidic carboxylic groups of the dye can occur. The resulting $\mathrm{Ti}^{+}$ions form insoluble complexes with chlorophyll dyes, causing precipitation of these complexes in the pores of the film. This gives rise to inactive dye molecules on the $\mathrm{TiO}_{2}$ surfaces [20, 23]. Based on this work, it has been found that the concentration of $90 \mathrm{mM}$ chlorophyll dye has good interaction with the $\mathrm{TiO}_{2}$ surfaces, due to the high dye loading value without producing the significant inactive dye precipitation effect.

\section{Conclusions}

Chlorophyll extracted from papaya leaves can be used as a dye sensitizer in DSSCs. However, the energy conversion efficiency is still lower than that of synthetic dye-based DSSCs. The N719 dye-based DSSCs achieved an efficiency of $1.293 \%$, while the highest efficiency of chlorophyll dyebased DSSCs was $0.094 \%$ at $90 \mathrm{mM}$. The variation in the chlorophyll dye solution concentration did not change the HOMO-LUMO energy level and $-\mathrm{COOH}$ functionalities. Increasing the dye solution concentrations also increased the efficiency of DSSCs because of the increase in the amount of dye adsorbed by $\mathrm{TiO}_{2}$. However, at concentrations above $90 \mathrm{mM}$, the efficiency of DSSCs decreased because of the precipitation of dye on the $\mathrm{TiO}_{2}$ nanostructure. This raises the number of inactive dye molecules on the surface of $\mathrm{TiO}_{2}$, preventing the electron injection processes in DSSCs.

\section{Nomenclature}

A: Intensity of the UV-Vis absorption (-)

$c$ : Solution concentration (molar)

$l$ : Path length of the light beam $(\mathrm{cm})$.

\section{Greek Letters}

$\varepsilon$ : Molar extinction coefficient $\left(\mathrm{M}^{-1} \mathrm{~cm}^{-1}\right)$

$\eta$ : Efficiency (\%).

\section{Competing Interests}

The authors declare that they have no competing interests.

\section{Acknowledgments}

The authors thank the Rector of Sebelas Maret University (UNS) and DP2M DIKTI for the financial support through the research Grant Nr.632/UN27.21/LT/2016.

\section{References}

[1] Y. Ooyama and Y. Harima, "Photophysical and electrochemical properties, and molecular structures of organic dyes for dyesensitized solar cells," ChemPhysChem, vol. 13, no. 18, pp. 40324080, 2012.

[2] Suyitno, A. Zainal, A. S. Ahmad, T. S. Argatya, and Ubaidillah, "Optimization parameters and synthesis of fluorine doped tin oxide for dye-sensitized solar cells," Applied Mechanics and Materials, vol. 575, pp. 689-695, 2014.

[3] S. Ito, T. N. Murakami, P. Comte et al., "Fabrication of thin film dye sensitized solar cells with solar to electric power conversion efficiency over 10\%," Thin Solid Films, vol. 516, no. 14, pp. 46134619, 2008. 
[4] M. Grätzel, "Dye-sensitized solar cells," Journal of Photochemistry and Photobiology C: Photochemistry Reviews, vol. 4, no. 2, pp. 145-153, 2003.

[5] J. Hu, J. Cheng, S. Tong, Y. Yang, M. Chen, and S. Hu, "Ag-doped $\mathrm{TiO}_{2}$ nanotube arrays composite film as a photoanode for enhancing the photoelectric conversion efficiency in DSSCs," International Journal of Photoenergy, vol. 2016, Article ID 2736257, 9 pages, 2016.

[6] M. Kouhnavard, N. Ahmad Ludin, B. Vazifehkhah Ghaffari, K. Sopian, N. Abdul Karim, and M. Miyake, "An efficient metal-free hydrophilic carbon as a counter electrode for dyesensitized solar cells," International Journal of Photoenergy, vol. 2016, Article ID 5186762, 7 pages, 2016.

[7] I. N. Obotowo, I. B. Obot, and U. J. Ekpe, "Organic sensitizers for dye-sensitized solar cell (DSSC): properties from computation, progress and future perspectives," Journal of Molecular Structure, vol. 1122, pp. 80-87, 2016.

[8] K. E. Jasim, S. Al-Dallal, and A. M. Hassan, "Henna (Lawsonia inermis L.) dye-sensitized nanocrystalline titania solar cell," Journal of Nanotechnology, vol. 2012, Article ID 167128, 6 pages, 2012.

[9] N. Li, N. Pan, D. Li, and S. Lin, "Natural dye-sensitized solar cells based on highly ordered $\mathrm{TiO}_{2}$ nanotube arrays," International Journal of Photoenergy, vol. 2013, Article ID 598753, 5 pages, 2013.

[10] R. Syafinar, N. Gomesh, M. Irwanto, M. Fareq, and Y. M. Irwan, "Chlorophyll pigments as nature based dye for dye-sensitized solar cell (DSSC)," Energy Procedia, vol. 79, pp. 896-902, 2015.

[11] S. Suyitno, T. J. Saputra, A. Supriyanto, and Z. Arifin, "Stability and efficiency of dye-sensitized solar cells based on papaya-leaf dye," Spectrochimica Acta-Part A: Molecular and Biomolecular Spectroscopy, vol. 148, pp. 99-104, 2015.

[12] Y. Dou, F. Wu, L. Fang et al., "Enhanced performance of dyesensitized solar cell using $\mathrm{Bi}_{2} \mathrm{Te}_{3}$ nanotube/ $\mathrm{ZnO}$ nanoparticle composite photoanode by the synergistic effect of photovoltaic and thermoelectric conversion," Journal of Power Sources, vol. 307, pp. 181-189, 2016.

[13] N. Sakai, T. Miyasaka, and T. N. Murakami, "Efficiency enhancement of $\mathrm{ZnO}$-based dye-sensitized solar cells by lowtemperature $\mathrm{TiCl}_{4}$ treatment and dye optimization," Journal of Physical Chemistry C, vol. 117, no. 21, pp. 10949-10956, 2013.

[14] Z.-S. Wang, H. Kawauchi, T. Kashima, and H. Arakawa, "Significant influence of $\mathrm{TiO}_{2}$ photoelectrode morphology on the energy conversion efficiency of N719 dye-sensitized solar cell," Coordination Chemistry Reviews, vol. 248, no. 13-14, pp. 1381-1389, 2004.

[15] T. P. Chou, Q. Zhang, B. Russo, G. E. Fryxell, and G. Cao, "Titania particle size effect on the overall performance of dyesensitized solar cells," Journal of Physical Chemistry C, vol. 111, no. 17, pp. 6296-6302, 2007.

[16] Z. Arifin, S. Soeparman, D. Widhiyanuriyawan, A. Purwanto, and Dharmanto, "Synthesis, characterisation, and fabrication hollow fibres of $\mathrm{Zn}$-doped $\mathrm{TiO}_{2}$ for dye-sensitized solar cells," Journal of Engineering Science \& Technology, In press.

[17] F. M. Rajab, "Effect of solvent, dye-loading time, and dye choice on the performance of dye-sensitized solar cells," Journal of Nanomaterials, vol. 2016, Article ID 3703167, 8 pages, 2016.

[18] M. Shaheer Akhtar, K. K. Cheralathan, J.-M. Chun, and O.B. Yang, "Composite electrolyte of heteropolyacid (HPA) and polyethylene oxide (PEO) for solid-state dye-sensitized solar cell," Electrochimica Acta, vol. 53, no. 22, pp. 6623-6628, 2008.
[19] J. M. Parnis and K. B. Oldham, "Beyond the beer-lambert law: the dependence of absorbance on time in photochemistry," Journal of Photochemistry and Photobiology A: Chemistry, vol. 267, pp. 6-10, 2013.

[20] F. A. S. Lima, I. F. Vasconcelos, and M. Lira-Cantu, "Electrochemically synthesized mesoporous thin films of $\mathrm{ZnO}$ for highly efficient dye sensitized solar cells," Ceramics International, vol. 41, no. 8, Article ID 10350, pp. 9314-9320, 2015.

[21] D. Zhao, T. Peng, L. Lu, P. Cai, P. Jiang, and Z. Bian, "Effect of annealing temperature on the photoelectrochemical properties of dye-sensitized solar cells made with mesoporous $\mathrm{TiO}_{2}$ nanoparticles," Journal of Physical Chemistry C, vol. 112, no. 22, pp. 8486-8494, 2008.

[22] W. P. Inskeep and P. R. Bloom, "Extinction coefficients of chlorophyll $\mathrm{a}$ and $\mathrm{b}$ in N,N-dimethylformamide and $80 \%$ acetone," Plant Physiology, vol. 77, no. 2, pp. 483-485, 1985.

[23] K. Keis, J. Lindgren, S.-E. Lindquist, and A. Hagfeldt, "Studies of the adsorption process of $\mathrm{Ru}$ complexes in nanoporous $\mathrm{ZnO}$ electrodes," Langmuir, vol. 16, no. 10, pp. 4688-4694, 2000. 

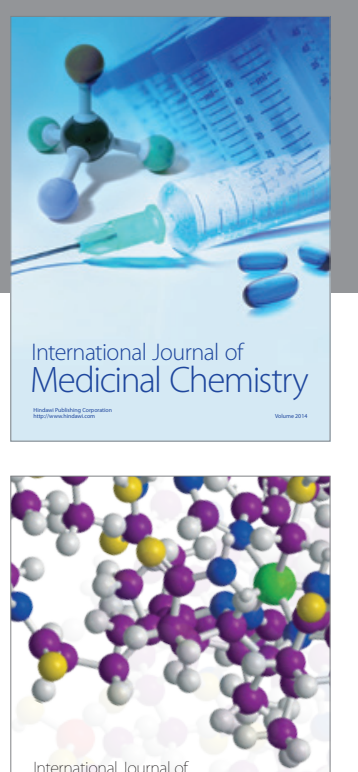

Carbohydrate Chemistry

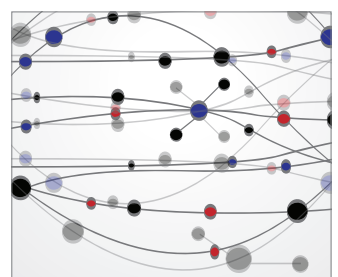

The Scientific World Journal
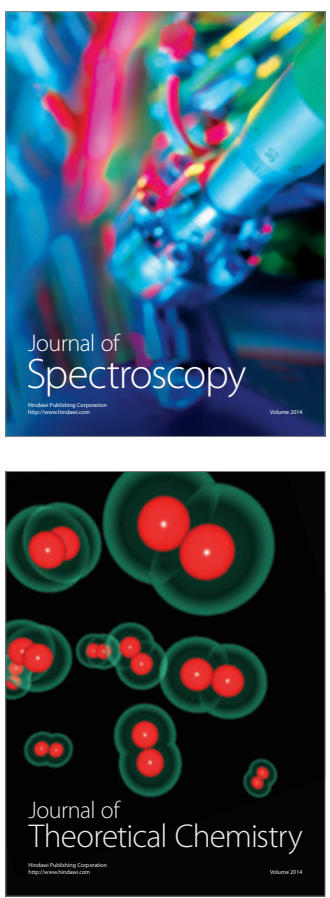
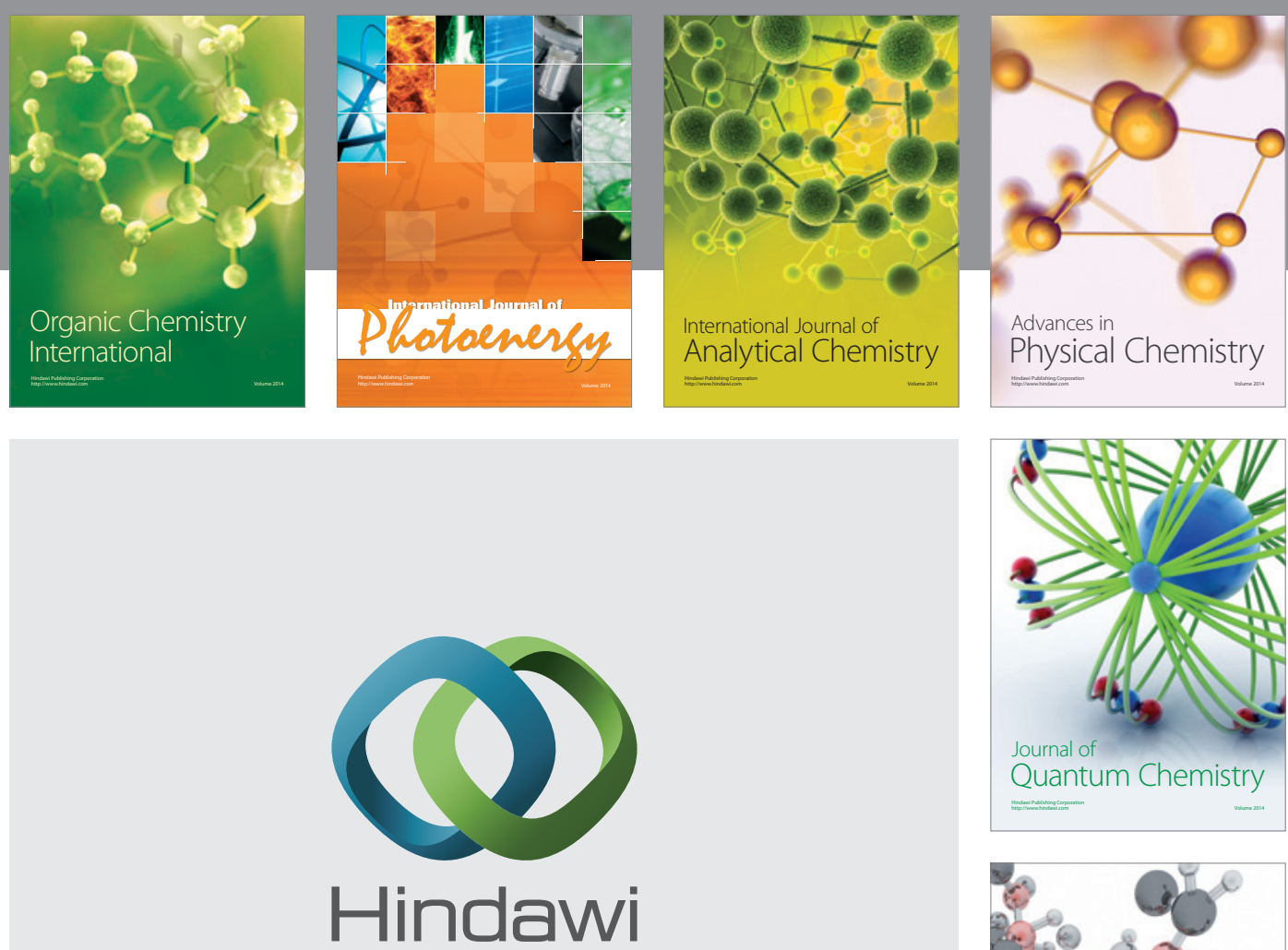

Submit your manuscripts at

https://www.hindawi.com

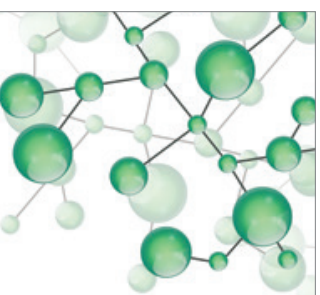

International Journal of

Inorganic Chemistry
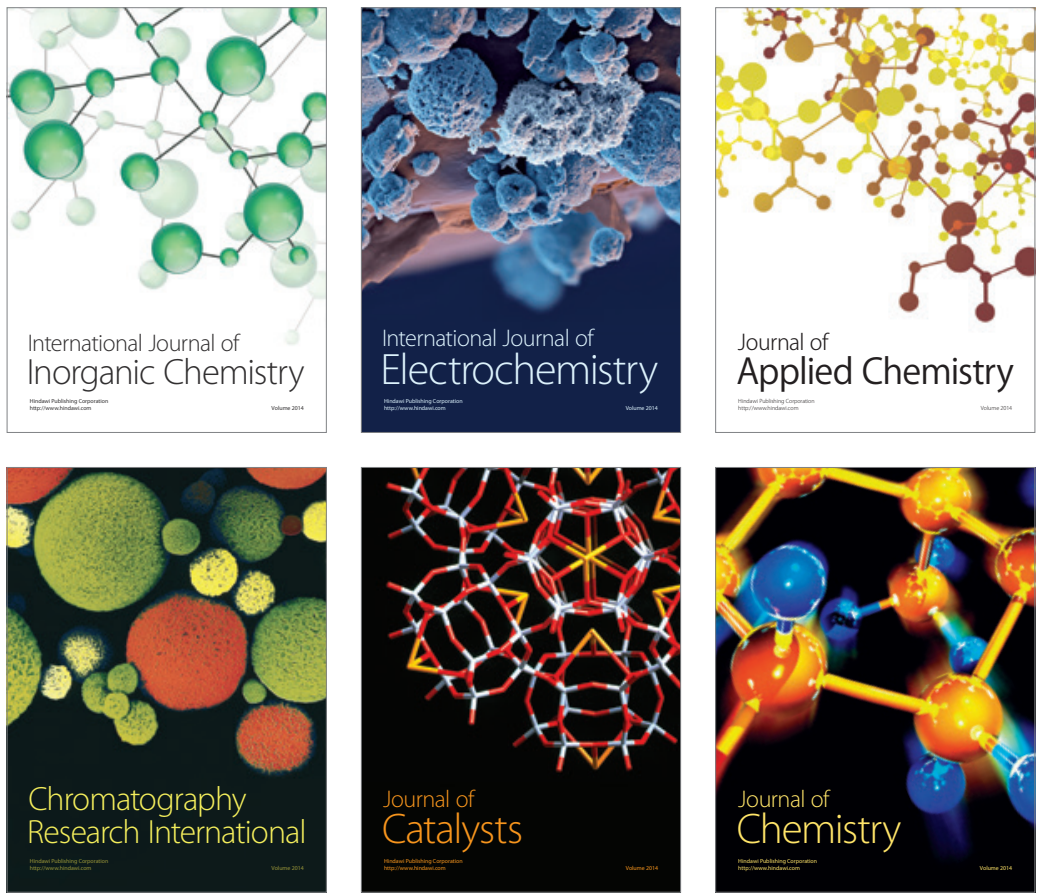

Journal of

Applied Chemistry
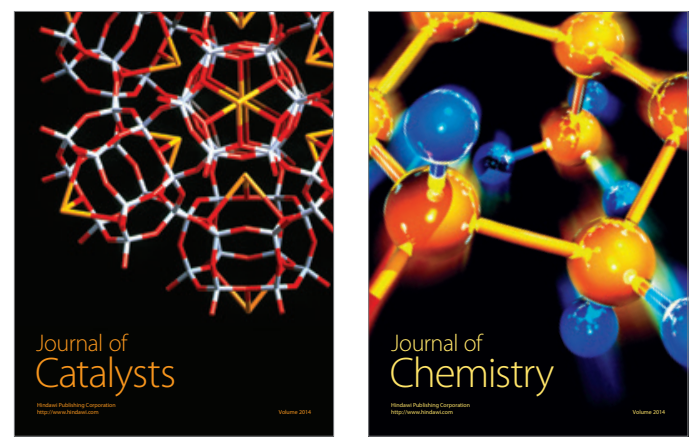
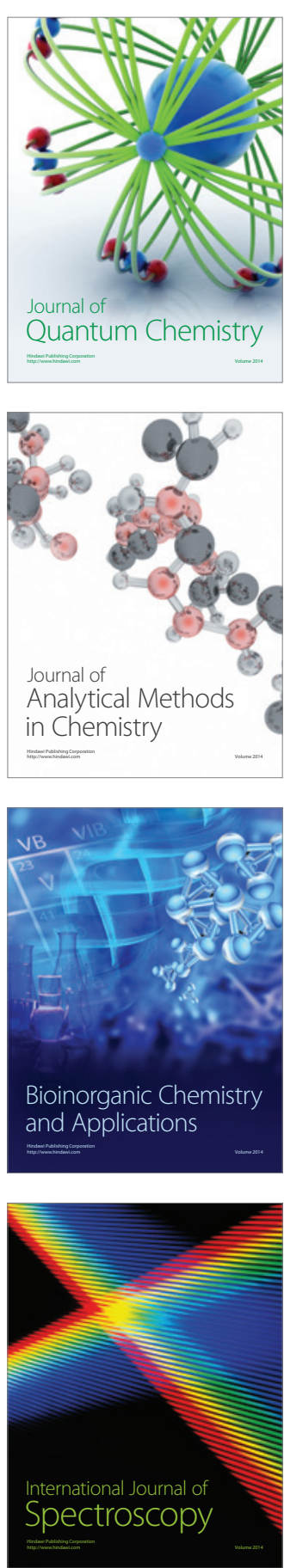